\title{
Pengaruh promosi staycation terhadap keputusan tamu menginap di alila hotel seminyak saat pandemi covid-19
}

\author{
Pande Putu Juniarta S.St. Par., M. Par ${ }^{1)}$ \\ Program Studi DIII Perhotelan, Institut Pariwisata dan Bisnis Internasional ${ }^{\mathbf{1}}$ \\ J1. Kecak Jl. Gatot Subroto Tim. No.12, Tonja, Denpasar, Kode pos : 80239 \\ Telp/Fax : (0361) 426699 Email : pandeputujuniarta@ipb-intl.ac.id
}

\begin{abstract}
Abstrak
Perkembangan pariwisa ta di Indonesia pada masa pandemi covid-19 mengalami penurunan yang sangat signifikan. Bali sebagai destinasi wisa ta utama di Indonesia juga mengalami hal yang sama. Hal ini berdampak secara langsung terhadap berbagai sektor utamanya sektor a komodasi perhotelan. Banyak hotel yang melakukan berba gai cara agar bisa bertahan pada era pandemi ini denga n melakukan stra tegi promosi. Sa lah satu strategi promosi yang dilakukan a dalah staycation. Alila hotel seminyak adalah salah sa tu hotel yang terdampak pandemi covid-19 y ang melakukan promosi staycation untuk menarik minat wisa tawan untuk menginap di hotel tersebut. Penelitian ini bertujuan untuk mengetahui pengaruh promosi staycation terhadap keputusan tamu menginap di Alila Hotel Seminyak pada era pandemi covid-19. Metodepenelitian yang digunakan dalam penelitian ini adalah deskriptif kuantitatif dengan analisis data regresi linear sederhana. Hasil penelitian menunjukkan adanya pengenuh signifika n antara promosi staycation terhadap keputu san tamu menginap di Alila Hotel Seminyak.
\end{abstract}

Kata kunci : promosi, staycation, keputusan menginap, Alila hotel seminyak

\section{Abstract}

The development of tourism n ndonesia during the COVID-19 pandemic has experienced a very significant decline. Bali as a major tourist destination $n$ ndonesia also experienced the same thing. This has a direct mpact on various sectors, especially the hotel accommodation sector. Many hotels are doing various ways in order to survive in this pandemic era by carrying out promotional strategies. One of the promotional strategies that $s$ carried out is a staycation. Alila Hotel Seminyak is one of the hotels affected by the COVID-19pandemic which is conducting a staycation promotion to attract tourists to stay at the hotel. This study aims to determine the effect of staycation promotions on guest decisions to stay at Alila Hotel Seminyak during the covid-19 pandemic era. The research method used $n$ this research s descriptive quantitative with simple linear regression data analysis. The results of the research show that there is a significant nfluence between staycation promotions on guest decisions to stay at Alila Hotel Seminyak.

Key word : promotion, staycation, guestdecision, Alila hotel seminyak

\section{PENDAHULUAN}

Perkembangan pariwisata di Indonesia pada masa pandemi covid-19 mengalami penurunan yang sangat signifikan, hal tersebut dapat dilihat dari angka tingkat kunjungan wisatawan pada tahun 2020 yang menurun drastis dari tahun 2019. Data dari kemenparenkraf tahun 2020 menunjukkan anggka tingkat kunjungan wisatawan mancanegara ke Indonesia pada tahun 2020 sebanyak 4.052 .923 atau mengalami penurunan sebanyak $74,84 \%$ dibandingkan dengan jumlah kunjungan wisatawan mancanegara ke Indoneisa pada tahun 2019 sebanyak 16.108.600 kunjungan. Secara lebih khusus, Bali sebagai destinasi wisata utama di Indonesia juga mengalami hal yang sama. Data dari badan pusata statistik provinsi Bali tahun 2020 menunjukkan total kunjungan wisatawan mancanegara ke Bali sepanjang 2020 sebanyak 1.050 .060 kunjungan, turun 54,47\% dari periode yang sama pada tahun sebelumnya. Hal ini berdampak secara langsung terhadap berbagai sektor utamanya sektor akomodasi perhotelan. Selama pandemi covid-19, banyak usaha akomodasi yang mengalami kesulitan dengan berkurangnya penjualan kamar akibat turunnya kunjungan wisatawan mancanegara. Berbagi upaya dilakukan oleh pengelola akomodasi untuk tetap bertahan dalam situasi pandemi mulai dari pemotongan gajih, penciutan karyawan, merumahkan karyawan bahkan sampai melakukan pemutusan hubungan 
kerja (PHK) kepada karyawan. Data dari PHRI menunjukkan ada 60 hotel yang menutup usahanya karena terdampak pandemic covid-19. Akan tetapi masih banyak hotel yang bisa bertahan menghadapi kondisi ini dengan memanfaatkan kunjungan wisatawan domestik. Selama masa pandemi, wisatawan domestik lebih banyak mendominasi kunjungan ke Bali, hal ini menjadi sangat baik bagi usaha akomodasi karena masih ada tamu yang menginap walaupun tingkat hunian kamar tidak seperti tahuntahun sebelumnya. Salah satu usaha akomodasi di Bali yang masih sanggup bertahan sampai saat ini adalah Alila Hotel Seminyak. Selama pandemi, Alila Hotel seminyak melakukan berbagai macam strategi untuk menarik wisatawan domestik menginap di hotel tersebut. Langkah-langkah strategis seperti promosi paket menginap menjadi strategi yang tepat dalam menarik minat wisatawan domestik untuk menginap. Walaupun mengalami penurunan yang signifikan pada tingkat hunian kamar dibandingkan sebelum pandemi, tingkat hunian kamar Alila Hotel Seminyak terbilang cukup stabli tiap bulannya saat masa pandemi. Hal tersbut dapat dilihat pada table dibawah ni

Table 1. Tingkat hunian kamar Alila Hotel Seminyak Januari - Mei 2021

\begin{tabular}{lll}
\hline No & Bulan & Occupancy \\
\hline 1 & Januari & $16,13 \%$ \\
2 & Februari & $9,42 \%$ \\
3 & Maret & $15,67 \%$ \\
4 & April & $18,92 \%$ \\
5 & Mei & $19,98 \%$ \\
\hline
\end{tabular}

Sumber : HRD Alila Hotel Seminyak, 2021

Dari table 1 diatas dapat dilihat bahwa tingkat hunian kamar Alila Hotel Seminyak terlihat stabil. Namun pada bulan februari terlihat terjadi penurunan dari bulan januari, hal ni dikarenakan adanya peraturan pemerintah yang membatasi perjalanan wisatawan domestik dikarenakan peningkatan jumlah kasus covid 19 di ndonesia. Akibatnya banyak terjadi pembatalan pemesanan kamar yang dilakukan oleh wisatawan yang secara langsung berdampak pada tingkat hunian kamar di Alila Hotel Seminyak. Setelah pembatasan mulai dilonggarkan, geliat perjalanan wisatwan domestik kembali melakukan pemesanan kamar, hal tersebut terlihat dari tingkat hunian kamar di Alila Hotel Seminyak mengalami pertumbuhan pada bulan Maret - Mei 2021. Peningkatan ini tidak lepas dari berbagai upaya promosi yang dilakukan oleh pihak hotel. Salah satu strategi promosi yang dilakukan adalah staycation. staycation adalah liburan yang dilakukan di negara sendiri, bukan di luar negeri, atau liburan yang dilakukan di rumah dan melibatkan perjalanan ke atraksi-atraksi lokal yang berada di sekitar area tempat tinggal, atau dengan kata lain, menjadi turis di kota sendiri. Dalam hal ini, staycation lebih menekannkan pada wisatawan domestic yang memanfaatkan waktu berlibur dengan mengnap di sarana akomodasi yang ada di negaranya sediri. staycation sendiri telah menjadi dikenal di Indonesia sejak awal 2010-an. Namun, trend staycation baru mengalami peningkatan minat di Indonesia, khususnya di kota-kota besar sejak awal 2018 dan sampai saat ini masih terus bertambah. Apalagi selama pandemi covid-19 dimana pembatasan dilakukan di berbagai wilayah, staycation mampu menjadi solusi bagi wisatawan domestik yang ingin berlibur. Berdasarkan strategi promosi staycation yang dilaksanakan oleh Alila Hotel Seminyak diharapkan akan mempengaruhi keputusan menginap di Alila Hotel Seminyak.

\section{METODE PENELITIAN}

Penelitian ini dilakukan pada Hotel llila Seminyak dari bulan Maret tahun 2021 sampai bulan Juni tahun 2021. Alila Hotel seminyak berlokasi di J1. Taman Ganesha J1. Petitenget No.9, Seminyak, Kec. Kuta Utara, Kabupaten Badung. Alila Hotel Seminyak berada pada lokasi yang sangat strategis di jantung pariwisata seminyak yang banyak terdapat destinasi wisata seperti pantai seminyak, pantai legian, Pantai petitenget dan berbagai pusat perbelanjaan. Selain itu, lokasi Alila Hotel Seminyak juga dekat dengan tempat hiburan seperti Potato head, Biku restaurant, W bar \& lounge, Motel Mexicola dan Seminyak square 
Jenis data yang digunakan dalam penelitian ini adalah data kuantitatif yaitu data yang dikumpulkan berupa angka atau numerik. Sumber data yang digunakan adalah data primer yaitu informasi yang diperoleh dari lokasi penelitian yang dilakukan melalui pengamatan langsung (observasi), questioner (angket) dan wawancara dan data sekunder yaitu informasi yang diperoleh dari buku dan situs internet.

Teknik pengumpulan data yang digunakan dalam penelitian ini adalah : 1) observasi yaitu teknik pengumpulan data yang dilakukaan melalui suatu pengamatan, dengan disertai pencatatanpencatatan terhadap keadaan atau prilaku objek sasaran (Abdurrahman, 2011), 2) wawancara yakni teknik pengumpulan data melalui proses tanya jawab lisan yang berlansung satu arah , artinya pertanyaan datang dari pihak yang mewawancarai dan jawaban diberikan oleh yang diwawancara (Abdurrahman, 2011)., 3) Studi kepustakaan metode pengumpulan data yang diarahkan kepada pencarian data dan informasi melalui dokumen-dokumen, baik dokumen tertulis, foto-foto, gambar, maupun dokumen elektronik yang dapat mendukung dalam proses penulisan ( Sugiyono, 2005)., 4) Kuesioner yakni teknik pengumpulan data yang dilakukan dengan cara memberikan seperangkat pertanyaan atau pernyataan tertulis kepada responden untuk dijawab. Adapun teknik penentuan sampel menggunakan Teknik purposive sampling yaitu teknik pengambilan sampel sumber data dengan pertimbangan tertentu. Alasan menggunakan teknik Purposive Sampling adalah karena tidak semua sampel memiliki kriteria yang sesuai dengan fenomena yang diteliti, dimana sampel yang diteliti pada penelitian ini adalah tamu yang menginap di Alila Hotel Seminyak. Ukuran sampel dihitung dengan menggunaan rumus Slovin (Husein Umar,2002:59). Berdasarkan rumus tersebut, dengan derajat kesalahan sebesar $10 \%$, maka jumlah responden yang dijadikan ukuran sampel dalam penelitian ini ialah sebanyak 100 responden. Kuesioner yang digunakan dalam penelitian ini adalah kuesioner tipe pilihan yang artinya tamu yang menginap yang menjadi responden diberikan alternatif jawaban yang telah disediakan dengan menggunakan skala likert. Jawaban setiap item instrument mempunyai gradasi dari sangat positif sampai negatif dengan nilai perhitungan sebagai berikut :

\section{$\frac{\text { Nilai Terting gi }- \text { Nilail Terendah }}{\text { Jumlah Kategori }}=$ Selisih Nilai Perkategori}

$$
\frac{5-1}{5}=0.80
$$

Berdasarkan rumus interval yang dijelaskan sebelumnya maka dapat disusun kategori sikap responden seperti Tabel 2 berikut ini:

Tabel 2. Kategori Penilaian Skala Likert

\begin{tabular}{|c|l|c|c|}
\hline No & \multicolumn{1}{|c|}{ Pilihan Jawab } & Skor & Interval \\
\hline 1 & Sangat Setuju & 5 & $4,21-5,00$ \\
\hline 2 & Setuju & 4 & $3,41-4,20$ \\
\hline 3 & Kurang Setuju & 3 & $2,61-3,40$ \\
\hline 4 & Tidak Setuju & 2 & $1,81-2,60$ \\
\hline 5 & Sangat TIdak Setuju & 1 & $1,00-1,80$ \\
\hline
\end{tabular}

Sumber: Hasil Modifikasi Skala Likert (Kusmayadi \& Endar, 2000:94)

Penelitian ini menggunakan teknik analisis data kuantitatif yaitu mengolah data dengan mentabulasi, menghitung dan menguji dengan menggunakan bantuan bantuan software SPSS. Adapun uji instrument yang digunakan yakni :1) Uji validitas yakni validitas menentukan alat ukur tersebut dapat digunakan untuk mengukur apa yang seharusnya diukur., 2) Uji reliabilitas yaitu uji reliabilitas atau keandalan intsrumen menentukan sejauh mana suatu pengkuran dapat memberikan hasil yang konsisten bila dilakukan pengukuran kembali dengan gejala yang sama., 3) Uji normalitas digunakan untuk menguji model regresi, variabel terikat, variabel bebas atau keduanya memiliki distribusi normal atau tidak., 4) Analisis regresi linear sederhana digunakan untuk melakukan 
prediksi seberapa besar nilai variabel dependent jika nilai independent dirubah., 5) Uji test untuk menguji apakah masing-masing variabel independen berpengaruh pada variabel dependen, dan 6) Koefisien determinasi digunakan untuk mengetahui seberapabesar persentase dari pengaruh variabel independen terhadap variabel dependen.

\section{HASIL PENELITIAN DAN PEMBAHASAN}

\subsection{Bentuk Promosi staycation di Hotel Alila Seminyak.}

Selama pandemic covid-19, Alila Hotel Seminyak membuat promo untuk meningkatkan tingkat hunian kamar. Salah satu promosi yang dilakukan oleh Hotel Alila seminyak adalah promosi staycation. Bentuk promo staycation di Hotel Alila Seminyak selama pandemi covid-19 adalah sebagai berikut :

\section{1) Long Stay Package}

Promo ini memberikan kesempatan bagi tamu yang menginap di Hotel Alila Seminyak untuk mendapatkan akses ke area umum yang langsung menghadap ke pantai, gratis pencucian pakaian, treatment Spa setiap seminggu sekali, dan kredit resor dengan nilai lebih dan manfaat lebih untuk masa inap yang lebih lama. Promo ini bisa didapatkan oleh tamu dengan mnginap minimal 7 hari atau lebih.

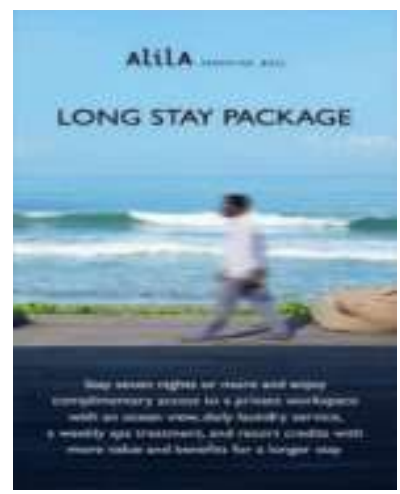

Gambar 1. Flyer long stay package

2) Friend and Family Previlage

Promo ini diperuntukkan untuk tamu dengan teman atau keluarga saat menginap di Alila Hotel Seminyak dengan manfaat anatara lain :

a. Upgrade gratis ke kamar dengan kategori suit

b. Makan pagi untuk 2 orang di Sea Salt Restaurant

c. Diskon 50\% untuk spa di Alila Spa

d. Diskon $20 \%$ untuk makanan dan minuman kecuali minuman beralkohol

e. Alila Happening (mengikuti aktiviatas harian hotel gratis)

f. 24 jam check in-check out

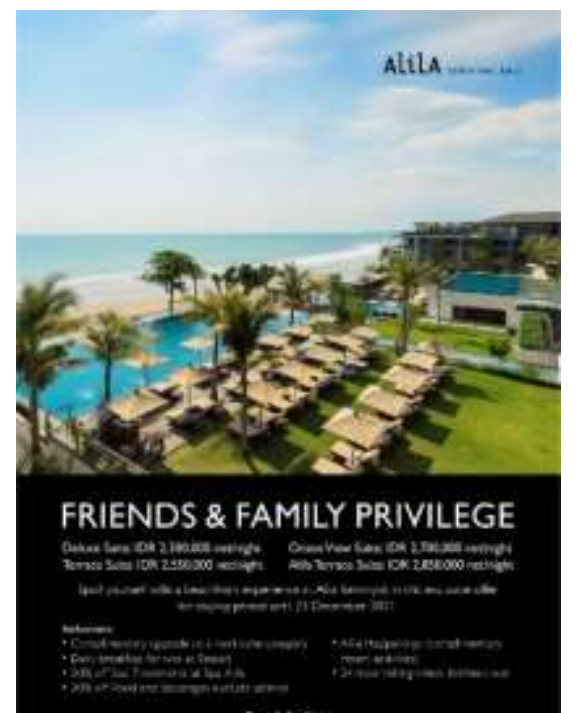




\section{Gambar 2. Flyer Friend \& Family Package}

Kedua promo staycation tersebut berlaku dari bulan Maret sampai dengan Desember 2021. Selain melakukan promosi pada website hotel, bentuk promosi staycation juga dilkukan secara langusng oleh seluruh karyawan hotel melalui social media masing-masing.

\subsection{Karakteristik responden}

Hasil penelitian yang dilaksanakan, dapat dijelaskan gambaran mengenai responden berdasarkan umur, jenis kelamin, pendidikan.

1) Responden Berdasarkan Umur

Komposisi responden berdasarkan umur dapat dilihat pada tabel 3 di bawah ini.

Tabel 3. Karakteristik Menurut Umur Responden

\begin{tabular}{ccc}
\hline Umur (tahun) & Jumlah (orang) & Presentase \\
\hline $17-27$ & 26 & $26 \%$ \\
\hline $28-38$ & 57 & $57 \%$ \\
\hline $39-49$ & 14 & $14 \%$ \\
\hline $50>$ & 3 & $3 \%$ \\
\hline Total & $\mathbf{1 0 0}$ & $\mathbf{1 0 0 \%}$ \\
\hline
\end{tabular}

Sumber : Hasil Kuesioner 2021

Berdasarkan Tabel 3 dapat dilihat bahwa responden umur 28 - 38 tahun sebanyak 57 orang $(57 \% \%)$ merupakan jumlah tertinggi dibandingkan dengan kelompok umur yang lain, hal ini mengindikasikan tamu yang menginap di Alila hotel seminyak berasal dari kalangan yang sudah berkeluarga.

2) Responden Berdasarkan Jenis Kelamin

Komposisi responden berdasarkan jenis kelamin dapat dilihat pada tabel 4 di bawah ini.

Tabel 4. Karakteristik Responden Berdasarkan Jenis Kelamin

\begin{tabular}{ccc}
\hline Jenis Kelamin & Jumlah (orang) & Presentase \\
\hline Laki-Laki & 52 & $52 \%$ \\
\hline Perempuan & 48 & $48 \%$ \\
\hline Total & $\mathbf{1 0 0}$ & $\mathbf{1 0 0 \%}$ \\
\hline
\end{tabular}

Sumber : Hasil Kuesioner 2021

Berdasarkan Tabel 4 dapat dilihat bahwajumlah responden laki-laki lebih banyak dibandingkan dengan responden perempuan walaupun pebedaan jumlah tersebut tidak signifikan, hal ini dikarenakan banyak pasangan suami istri yang menginap di Alila Hotel Seminyak.

3) Responden Berdasarkan Pendidikan

Komposisi responden apabila diklasifikasikan berdasarkan pendidikan dapat dilihat pada tabel 5 di bawah ini.

Tabel 5. Karakteristik Responden Berdasarkan Pendidikan

\begin{tabular}{ccc}
\hline Pendidikan & Jumlah (orang) & Presentase \\
\hline SMA/SMK & 6 & $6 \%$ \\
\hline Diploma & 39 & $39 \%$ \\
\hline
\end{tabular}




\begin{tabular}{ccc}
\hline Sarjana & 55 & $55 \%$ \\
\hline Total & $\mathbf{1 0 0}$ & $\mathbf{1 0 0 \%}$ \\
\hline
\end{tabular}

Sumber : Hasil Kuesioner 2021

Berdasarkan Tabel 5, dapat dilihat bahwa, jumlah responden yang pendidikan sarjana lebih banyak dari pada tingkat pendidikan lainnya hal ini mengidikasikan responden dengan tingkat pendidikan tinggi memiliki minat untuk menginap dihotel lebih banyak dibandingkan responden dengan tinggkat Pendidikan yang lebih rendah.

\subsection{Hasil Penilaian Responden}

Tabel 6. Hasil Penilaian Responden terhadap Promosi Staycation

\begin{tabular}{|c|c|c|c|c|c|c|c|c|c|c|}
\hline \multirow[t]{3}{*}{ No } & \multirow{3}{*}{$\begin{array}{c}\text { Indikator } \\
\text { variabel }\end{array}$} & \multicolumn{5}{|c|}{ Sekor Frekuensi Pernyataan } & \multirow{3}{*}{$\begin{array}{r}\text { Total } \\
\text { Sekor }\end{array}$} & \multirow{3}{*}{$\begin{array}{c}\text { Jumlah } \\
\text { Responden }\end{array}$} & \multirow{3}{*}{$\begin{array}{l}\text { Rata } \\
\text {-rata } \\
\text { sekor }\end{array}$} & \multirow[t]{3}{*}{ Ket } \\
\hline & & SS & $\mathbf{S}$ & KS & TS & STS & & & & \\
\hline & & 5 & 4 & 3 & 2 & $\mathbf{1}$ & & & & \\
\hline 1 & $\begin{array}{l}\text { Promosi } \\
\text { staycation } \\
\text { memudahkan } \\
\text { anda dalam } \\
\text { menentukan } \\
\text { hotel tempat } \\
\text { menginap } \\
\text { saat pandemi } \\
\text { covid-19 }\end{array}$ & 45 & 48 & 6 & 1 & 0 & 437 & 100 & 4,37 & $\begin{array}{l}\text { Sangat } \\
\text { Setuju }\end{array}$ \\
\hline 2 & $\begin{array}{l}\text { Promosi } \\
\text { staycation } \\
\text { memberikan } \\
\text { banyak } \\
\text { penawaran } \\
\text { dan promo } \\
\text { saat pandemi } \\
\text { covid-19 }\end{array}$ & 63 & 35 & 2 & 0 & 0 & 461 & 100 & 4,61 & $\begin{array}{l}\text { Sangat } \\
\text { Setuju }\end{array}$ \\
\hline 3 & $\begin{array}{l}\text { Promosi } \\
\text { staycation } \\
\text { menjadi } \\
\text { pilihan } \\
\text { dalam } \\
\text { memilih } \\
\text { hotel saat } \\
\text { pandemi } \\
\text { covid-19 }\end{array}$ & 34 & 49 & 15 & 2 & 0 & 415 & 100 & 4,15 & Setuju \\
\hline 4 & $\begin{array}{l}\text { Promosi } \\
\text { staycation } \\
\text { memberikan } \\
\text { penawaran } \\
\text { harga yang } \\
\text { kompetitif } \\
\text { saat pandemi } \\
\text { covid-19 }\end{array}$ & 66 & 31 & 2 & 1 & 0 & 462 & 100 & 4,62 & $\begin{array}{l}\text { Sangat } \\
\text { Setuju }\end{array}$ \\
\hline \multicolumn{2}{|c|}{ Total } & 208 & 163 & 25 & 4 & 0 & & & 17,15 & Sangat \\
\hline \multicolumn{2}{|c|}{ Rata - rata } & 52 & 40,75 & 6,25 & $\mathbf{1}$ & $\mathbf{0}$ & & & 4,29 & Setuju \\
\hline
\end{tabular}

Sumber : Hasil Penelitian, 2021

Berdasarkan Tabel 6 dapat dilihat bahwa promosi staycation sangat diminati oleh responden. Hasil tabulasi responden secara menyeluruh mendapatkanskor 4,29 yang berada pada kriteria sangat setuju. Skor tertinggi beradapada indikator "Promosi staycation memberikan penawaran harga yang 
kompetitif saat pandemi covid-19" (4,62). Skor terendah berada pada indikator "promosi staycation menjadi pilihan dalam memilih hotel saat pandemi covid-19" $(4,15)$.

Tabel 7. Hasil Penilaian Responden terhadap keputusan menginap

\begin{tabular}{|c|c|c|c|c|c|c|c|c|c|c|}
\hline \multirow[t]{3}{*}{$\overline{\text { No }}$} & \multirow{3}{*}{$\begin{array}{l}\text { Indikator } \\
\text { variabel }\end{array}$} & \multicolumn{5}{|c|}{ Sekor Frekuensi Pernyataan } & \multirow{3}{*}{$\begin{array}{l}\text { Total } \\
\text { Sekor }\end{array}$} & \multirow{3}{*}{$\begin{array}{c}\text { Jumlah } \\
\text { Responden }\end{array}$} & \multirow{3}{*}{$\begin{array}{l}\text { Rata } \\
\text {-rata } \\
\text { sekor }\end{array}$} & \multirow[t]{3}{*}{ Ket } \\
\hline & & SS & $\mathbf{S}$ & KS & TS & STS & & & & \\
\hline & & 5 & 4 & 3 & 2 & 1 & & & & \\
\hline 1 & $\begin{array}{l}\text { Saya } \\
\text { menjadikan } \\
\text { Alila Hotel } \\
\text { Seminyak } \\
\text { sebagai } \\
\text { pemenuhan } \\
\text { kebutuhan } \\
\text { menginap } \\
\text { saat pandemi } \\
\text { covid-19 }\end{array}$ & 31 & 43 & 15 & 1 & 0 & 374 & 100 & 3,74 & Setuju \\
\hline 2 & $\begin{array}{l}\text { Alila Hotel } \\
\text { Seminyak } \\
\text { menjadi } \\
\text { pertimbangan } \\
\text { saya untuk } \\
\text { menginap } \\
\text { pada saat } \\
\text { pandemi } \\
\text { covid-19 }\end{array}$ & 34 & 57 & 9 & 0 & 0 & 425 & 100 & 4,25 & $\begin{array}{l}\text { Sangat } \\
\text { Setuju }\end{array}$ \\
\hline 3 & $\begin{array}{l}\text { Keputusan } \\
\text { saya } \\
\text { menginap di } \\
\text { Alila Hotel } \\
\text { Seminyak } \\
\text { adalah } \\
\text { keputusan } \\
\text { yang } \\
\text { tepat saat } \\
\text { pandemi } \\
\text { covid-19 }\end{array}$ & 26 & 55 & 13 & 6 & 0 & 401 & 100 & 4,01 & Setuju \\
\hline 4 & $\begin{array}{l}\text { Saya } \\
\text { berkeinginan } \\
\text { menginap } \\
\text { kembali di } \\
\text { Alila Hotel } \\
\text { Seminyak di } \\
\text { waktu yang } \\
\text { akan } \\
\text { datang. }\end{array}$ & 22 & 54 & 19 & 5 & 0 & 393 & 100 & 3,93 & Setuju \\
\hline Tot & & 113 & 209 & 56 & 12 & $\mathbf{0}$ & & & $\mathbf{1 5 , 9 3}$ & Sangat \\
\hline$\underline{\mathbf{R a}}$ & - rata & $\mathbf{2 7 , 7 5}$ & $\mathbf{5 2 , 2 5}$ & 14 & 6 & $\mathbf{0}$ & & & 3,98 & Setuju \\
\hline
\end{tabular}

Sumber : Hasil Penlitian, 2021

Berdasarkan Tabel 7 dapat dilihat bahwa keputusan tamu menginap di Alila Hotel Seminyak baik. Hasil tabulasi responden secara menyeluruh mendapatkan skor 3,98 yang berada pada kriteria setuju. Skor tertinggi beradapada indikator "Alila Hotel Seminyak menjadi pertimbangan saya untuk menginap pada saat pandemi covid-19" (4,25). Skor terendah berada pada indikator "Saya 
menjadikan Alila Hotel Seminyak sebagai pemenuhan kebutuhan menginap saat pandemi covid-19" $(3,74)$.

\subsection{Hasil Uji Instrumen}

Uji instrument penelitian ini dilakukan dengan uji validitas, uji reliabilitas, uji normalitas, koefisien deterinasi, uji hipotesis (Uji t-test). Instrumen yang diuji adalah kuesioner yang berisi 8 pernyataan. Sebuah instrumen dianggap memiliki validitas yang tinggi jika instrumen tersebut benar-benar dapat dijadikan alat untuk mengukur sesuatu secara tepat. Selanjutnya uji reliabilitas untuk mengetahui instrument reliabel bila mampu mengukur sesuatu dengan hasil yang konsisten. Uji normalitas digunakan untuk menguji apakah dalam model regresi, variabel terikat, variabel bebas atau keduanya memiliki distribusi normal atau tidak. Model regresi yang baik adalah yang memiliki distribusi data normal atau yang mendekati normal. Koefisien determinasi digunakan untuk mengetahui seberapa besar persentase dari pengaruh variabel independen terhadap variabel dependen yaitu pengaruh promosi staycation terhadap produktivitas. Sedangkan uji hipotesis (uji t-test) dilakukan secara parsial terhadap parameter dilakukan dengan menggunakan uji ttest. Pengujian ini dilakukan untuk mengetahui signifikansi perbedaan 2 buah mean yang berasal dari 2 buah distribusi atau menguji secara parsial masing-masing setiap variabel dengan membandingkan nilai t-hitungdengan t-tabel

\subsubsection{Uji Validitas}

Uji validitas menentukan alat ukur tersebut dapat digunakan untuk mengukur apa yang seharusnya diukur (Sugiyono, 2017:203). Uji validitas dapat dilakukan terhadap data yang didapatmelalui kuesioner. Uji validitas dilakukan untuk menguji hasil kuesioner agar dapat dikatakan valid. Indikator yang diukur yakni indikator promosi staycation (X) dan keputusan tamu menginap (Y). pada penelitian ini data diolah menggunakanbantuan program SPSS for Windows versi 23.0. Penelitian ini menggunakan tingkat signifikansi sebesar 5\% atau 0.05 . Item pada kuesioner dinyatakan valid apabila nilai $r$-hitung yang dimiliki tiap indikator lebih besar daripada r-tabel ( $r$-hitung $>r$-tabel). Uji validitas dilakukan pada 100 responden. Hasil uji validitas dapat dilihat berdasarkan tabel 8 berikut.

Table 8. Uji Validitas

\begin{tabular}{lcccc}
\hline \multicolumn{1}{c}{ Variabel } & Item & $\mathrm{r}_{\text {hitung }}$ & $\mathrm{r}_{\text {tabel }}$ & Keterangan \\
\hline Promosi & $\mathrm{X} 1$ & 0.455 & 0.1946 & VALID \\
Staycation $(\mathrm{X})$ & $\mathrm{X} 2$ & 0.782 & 0.1946 & VALID \\
& $\mathrm{X} 3$ & 0.639 & 0.1946 & VALID \\
& $\mathrm{X} 4$ & 0.532 & 0.1946 & VALID \\
Keputusan Tamu & $\mathrm{Y} 1$ & 0.588 & 0.1946 & VALID \\
Menginap (Y) & $\mathrm{Y} 2$ & 0.503 & 0.1946 & VALID \\
& $\mathrm{Y} 3$ & 0.782 & 0.1946 & VALID \\
& $\mathrm{Y} 4$ & 0.853 & 0.1946 & VALID \\
\hline
\end{tabular}

Sumber : Hasil output SPSS 2021

Berdasarkan pada Tabel 8 dapat dilihat bahwa r-hitung indikator yang diuji dalam penelitian ini keseluruhan menghasilkan nilai positif dan lebih besar dari nilai $r$-tabel. Sehingga dapat disimpulkan bahwa item-item pernyataan indikator dalam kuesioner ini dinyatakan valid.

\subsubsection{Uji Reliabilitas}

Uji reliabilitas atau keandalan intsrumen menentukan sejauh mana suatu pengkuran dapat memberikan hasil yang konsisten bila dilakukan pengukuran kembalidengan gejala yang sama (Sugiyono, 2017:209). Rumus mengenai uji reliabilitas menggunakan rumus Cronbach Alpha $>0.60$ yang diolah menggunakan bantuan program SPSS (Statistic Package of Social Science) for Windows 23.0. Uji reliabilitas adalah pengujian yang mengukur tingkat konsisten atau kestabilan data kuesioner. Suatu kuesioner dikatakan reliabel atau handal jika jawaban seseorang terhadap pernyataan konsisten 
dari waktu ke waktu. Reliabilitas diukur dengan uji statistik cronbach's alpha $(\alpha)$. Suatu variabel dikatakan reliabel jika memberikan nilai cronbach' alpha $>0,60$. Adapun hasil uji reliabilitas dapat dilihat pada tabel berikut.

Table 9. Hasil Uji Reliabilitas

\begin{tabular}{clcc}
\hline No & Variabel & Cronbatch's Alpha & Hasil \\
\hline 1 & Promosi Staycation (X) & 0.695 & Reliabel \\
2 & Keputusan Tamu Menginap (Y) & 0.734 & Reliabel \\
\hline
\end{tabular}

Sumber : Hasil output SPSS 2021

Hasil penelitian reliabilitas dari variabel bebas maupun variabel terikat dalam penelitian ini menunjukkan koefisien yang lebih besar dari 0.60 sehingga dapat disimpulkan variable bebas maupun varibel terikat sudah reliabel.

\subsubsection{Uji Normalitas}

Uji normalitas bertujuan untuk menguji apakah dalam model regresi, variabel terikat, variabel bebas atau keduanya memiliki distribusi normal atau tidak. Model regresi yang baik adalah yang memiliki distribusi data normal atau yang mendekati normal. Pengujian normalitas data dalam penelitian ini dilakukan dengan menggunakan statistic Kolmogorov-Smirnov atau K-S dengan bantuan program SPSS (Statistic Package of Social Science) for Windows versi 23.0.

Tabel 10. Hasil Uji Normalitas.

\section{One-Sample Kolmogorov-Smirnov Test}

\begin{tabular}{|ll|r|}
\hline & & \multicolumn{1}{|c|}{ Unstandardized Residual } \\
\hline $\mathrm{N}$ & & 30 \\
Normal Parameters ${ }^{\mathrm{a}, \mathrm{b}}$ & Mean & .0000000 \\
& Std. Deviation & 1.66000406 \\
Most Extreme & Absolute & .128 \\
Differences & Positive & .096 \\
& Negative & -.128 \\
Test Statistic & & .128 \\
Asymp. Sig. (2-tailed) & & .200 \\
\hline
\end{tabular}

Sumber : Hasil output SPSS 2021

Hasil uji normalitas Kolmogorov-Smirnov Test menunjukkan bahwa berdasarkan nilai Sig (2tailed), dapat dilihat bahwa sig (2-tailed) $(0,200)>$ dari level of significant $(0,05)$, sehingga dapat disimpulkan bahwa variabel promosi staycation terhadap keputusan tamu menginap normal.

\subsubsection{Analisis Regresi Sederhana}

Analisis hasil regresi linier sederhana bertujuan untuk mengetahui pengaruh satu variabel bebas, promosi staycation (X) terhadap satu variabel tak bebas keputusan tamu menginap (Y) apakah positif atau negatif untuk memprediksi besaran nilai dari variabel terikat (dependent).

Table 11. Hasil Analisis Regresi Linear Sederhana

\section{Coefficients}

\begin{tabular}{|l|c|c|c|c|c|}
\hline \multirow{4}{*}{ Model } & \multicolumn{4}{|c|}{} & Standardized \\
Unstandardized Coefficients & Coefficients & & \\
\cline { 2 - 4 } & $\mathrm{B}$ & Std. Error & Beta & $\mathrm{t}$ & Sig. \\
\hline
\end{tabular}




\begin{tabular}{|l|l|r|r|r|r|r|}
\hline \multirow{2}{*}{1} & (Constant) & 1.973 & 2.085 & & 12.946 & .000 \\
\cline { 2 - 7 } & Promosi Staycation & .862 & .166 & .700 & 5.186 & .000 \\
\hline
\end{tabular}

Sumber : Hasil output SPSS 2021

Berdasarkan Tabel 11 diperoleh hasil $\mathrm{Y}=1.973,0.862 \mathrm{X}$, persamaan yang diperoleh dapat menjelaskan pola pengaruh promosi staycation $(\mathrm{X})$ terhadap variabel terikat keputusan tamu menginap (Y) sebagai berikut:

1. Constanta $(\alpha)=\mathrm{Y}$ adalah besaran nilai variabel dependent (kinerja), yaitu sebesar 1.973.

2. Koefisien regresi $(\mathrm{b})=0.864$ yang mengartikan besaran nilai yang dipengaruhi oleh variabel independent (promosi staycation)

3. Kesimpulannya adalah bahwa terdapat pengaruh yang positif antara promosi staycation terhadap keputusan tamu menginap di Alila Hotel seminyak. Bila X (promosi staycation bertambah sebesar 1 (satu) satuan, maka nilai Y (keputusan tamu menginap) akan meningkat sebesar 0.862 atau $86 \%$.

\subsubsection{Hasil Uji Hipotetsis (Uji test)}

Pengujian yang dilakukan secara parsial terhadap parameter dilakukan dengan menggunakan uji t-test. Pengujian ini dilakukan untuk mengetahui signifikansi perbedaan 2 buah mean yang berasal dari 2 buah distribusi atau menguji secara parsial masing-masing setiap variabel dengan membandingkan nilai thitung dengan ttabel. Dasar pemikiran Uji t dalam penelitian ini, yakni :

1) $\mathrm{Ha}=$ Ada pengaruh positif dan signifikan antara promosi staycation $(\mathrm{X})$ terhadap keputusan tamu menginap (Y).

2) $\mathrm{H} 0=$ Tidak ada pengaruh yang positif dan signifikan antara promosi staycation $(\mathrm{X})$ terhadap keputusan tamu menginap (Y).

Tabel 12. Hasil Uji t dapat dilihat sebagai berikut :

Coefficients $^{a}$

\begin{tabular}{|c|c|c|c|c|c|c|}
\hline \multirow{2}{*}{\multicolumn{2}{|c|}{ Model }} & \multicolumn{2}{|c|}{ Unstandardized Coefficients } & \multirow{2}{*}{$\begin{array}{c}\text { Standardized } \\
\text { Coefficients }\end{array}$} & \multirow[b]{2}{*}{$\mathrm{t}$} & \multirow[b]{2}{*}{ Sig. } \\
\hline & & $\mathrm{B}$ & Std. Error & & & \\
\hline \multirow[t]{2}{*}{1} & (Constant) & 1.973 & 2.085 & & 12.946 & .000 \\
\hline & Promosi Staycation & .862 & .166 & .700 & 5.186 & .000 \\
\hline
\end{tabular}

Sumber : Hasil output SPSS 2021

Berdasarkan Tabel 12 dapat dilihat bahwahasil uji - $\mathrm{t}$ dalam penelitian ini variabel bebas memiliki taraf signifikansi motivasi kerja (X) sebesar 0,000. Pengaruh nyata promosi staycation terhadap keputusan tamu menginap diuji dengan distribusi t dengan menggunakan level of significant $5 \%$, serta degree of freedom $(\mathrm{df})=100-1-1=98$.

Keterangan :

$\alpha=$ signifikansi $=0,05$

$\mathrm{n}=$ Jumlah responden

$\mathrm{K}=$ Jumlah variabel bebas

Sehingga mendapatkan hasil :

$\mathrm{t}$-tabel $=(0,05 / 2 ; 100-1-1) \mathrm{t}$-tabel $=(0,025 ; 98)$ 
Daerah penerimaan dan penolakan H0 dapat dilihat pada gambar 3 berikut ini:

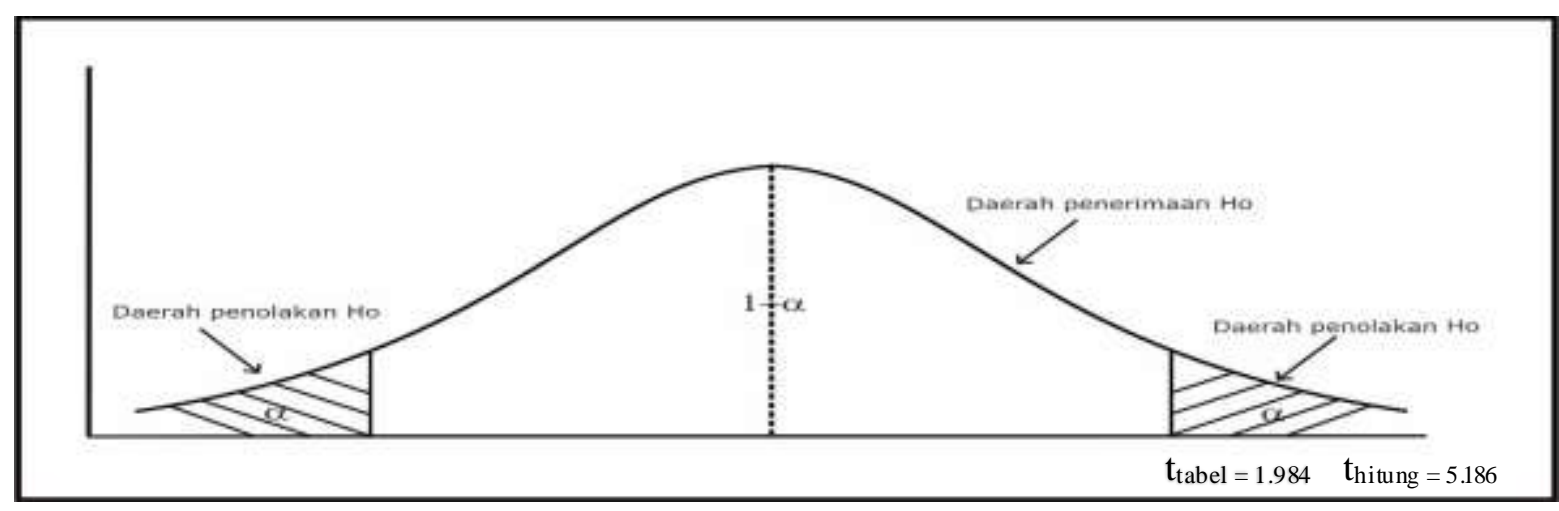

Sumber : Hasil pengolahan data 2021

Gambar 3. Dearah penerimaan dan penolakan H0

Berdasarkan kurva diatas, maka diperoleh promosi staycation $\mathrm{t}_{\text {hitung }}(5.186)>\mathrm{t}_{\text {tabel }}(1.984)$ ini berarti terdapat pengaruh yang signifikan antara promosi staycation terhadap keputusan tamu menginap di Alila Hotel Seminyak.

\subsubsection{Koefisien Determinasi}

Koefisien determinasi digunakan untuk mengetahui seberapa besar persentase dari pengaruh variabel independe terhadap variabel dependen.

Tabel 13. Hasil Koefisien Determinasi :

\section{Model Summary}

\begin{tabular}{|c|c|c|c|c|}
\hline Model & $\mathrm{R}$ & R Square & Adjusted R Square & Std. Error of the Estimate \\
\hline 1 & $.562^{\mathrm{a}}$ & .361 & .295 & .823 \\
\hline
\end{tabular}

Sumber : Hasil Output SPSS 2021

Dari hasil output diatas dapat dilihat bahwa terdapat hubungan antara promosi staycation dengan keputusan menginap tamu sebesar 0.562 atau $56,2 \%$ yang berarti bahwa nilai korelasi promosi staycation dengan keputusan tamu menginap berada pada tingkat sedang atau kategori sedang. Selanjutnya untuk koefesien determinan menunjukan hasil sebesar 0,316 atau 31,6\%. Nilai koefesien determinan menunjukan bahwa variabel promosi staycation memberikan kontribusi sebesar 31,6\% dalam mempengaruhi keputusan menginap, dan sisanya dipengaruhi oleh faktor-faktor lain yang tidak diteliti dalam penelitian ini. Sehingga promosi staycation yang dilaksanakan oleh Hotel Alila Seminyak dapat dijadikan salah satu strategi dalam hal meningkatkan keputusan menginap tamu.

\section{KESIMPULAN}

Berdasarkan hasil penelitian yang telah dilakukan tentang pengaruh promosi staycation terhadap keputusan tamu menginap di Alila hotel seminyak maka dapat disimpulkan bahwa : 1). variabel promosi staycation $(\mathrm{X})$ menunjukan pengaruh yang positif dan signifikan terhadap variable keputusan tamu menginap (Y) di Alila hotel seminyak pada masa pandemi covid-19. 2). variabel promosi staycation memberikan kontribusi sebesar 31,6\% dalam mempengaruhi keputusan tamu menginap di Alila hotel seminyak pada masa pandemi covid-19. 


\section{UCAPAN TERIMA KASIH}

Penulis mengucapkan terima kasih kepada pihak-pihak yang sudah terlibat dalam penulisan penelitian ini diantaranya Kadek Siska Dinayanti S.Tr. Keb selaku istri penulis yang senantiasa memberikan motivasi dan dorongan selama penulis melakukan penelitian ini. Selanjutnya terimakasih kepada Institut Pariwisata dan Bisnis Internasional sebagai Homebase peneliti sebagai dosen tetap. Dr. Putu Sucita Yanthy SS.,M.Par selaku editor jurnal kepariwisataan dan hospitality yang telah membantu penerbitan penelitian ini sebagai artikel ilmiah. Selanjutnya penulis mengucapkan terima kasih kepada manajemen alila Hotel Seminyak yang telah memberikan izin, informasi dan data pada penelitian ini.

\section{DAFTAR PUSTAKA}

Abdurrahman Fatoni, Metodologi Penelitian dan Teknik Penyususna Skripsi (Jakarta: Rineka Cipta,2011), hlm.104.

bali.bps.go.id, 2020. "Perkembangan-pariwisata-provinsi-bali-agustus-2020"

https://bali.bps.go.id/pressrelease/2020/10/01/717333/perkembangan-pariwisata-provinsibali-agustus-2020.html (diakses pada tangal 13 Juli 2021)

Basu Swasta, Dharmesta dan Irawan, (2008) Manajemen Pemasaran Modern, Liberty, Yogyakarta.

Databoks.katadata.co.id, 2020. "wisman-ke-bali-hanya-36-orang-turun-hampir-100-pada-mei-2020" https://databoks.katadata.co.id/datapublish/2020/07/13/wisman-ke-bali-hanya-36-orangturun-hampir-100-pada-mei-2020 (diakses pada tangal 13 Juli 2021)

Fajar, Laksana, 2008. Manajemen Pemasaran. Yogyakarta: Penerbit Graha Ilmu

Fandy Tjiptono, 2008.Strategi Pemasaran, Edisi III, Yogyakarta : CV. Andi Offset

Gitosudarmo, Indriyo, Manajemen Pemasaran, Yogyakarta: BPFE, 2014.

kemenparekraf.go.id, 2020. "Kunjungan-Wisatawan-Mancanegara-2020" https://kemenparekraf.go.id/statistik-wisatawan-mancanegara/Statistik-KunjunganWisatawan-Mancanegara-2020 (diakses pada tangal 13 Juli 2021)

Kotler, P. \& Keller, K.L. (2012), Manajemen Pemasaran Jilid I Edisi ke 12. Jakarta: Erlangga.

Kusmayadi dan Endar Sugiarto. 2000. Metodologi Penelitian dalam Bidang Kepariwisataan. Jakarta: PT.Gramedia Pustaka Utama.

Merdeka.com, 2020. dampak-pandemi-corona-60-hotel-di-bali-akan-dijual.” https://www.merdeka.com/peristiwa/dampak-pandemi-corona-60-hotel-di-bali-akandijual.html (diakses pada tangal 13 Juli 2021)

SK Mentri Perhubungan RI No. 241/4/70 tanggal 15 Agustus 1970.

Sugiyono. (2014). Metode Penelitian Pendidikan Pendekatan Kuantitatif, Kualitatif, dan R\&D. Bandung: Alfabeta.

Umar, Husein. 2002. Metodologi Penelitian Aplikasi dalam pemasaran. edisi II, Jakarta: PT. Gramedia Pustaka Utama

Widanaputra A.A, Herkulanus, B. S., Dodik, A, \& Ratna, S. 2009. Akuntansi Perhotelan Pendekatan Informasi. Yogyakarta: Graha Ilmu 